\title{
Firms' asset holdings and inflation expectations
}

\section{CAMA Working Paper 61/2020 June 2020}

\section{Saten Kumar}

School of Economics, Auckland University of Technology

Centre for Applied Macroeconomic Analysis, ANU

\section{Abstract}

This paper investigates the relationship between firms' inflation expectations and their holdings of liquid assets. We implement a new quantitative survey of firms' expectations about inflation in New Zealand. We find that firms that hold more shares of liquid assets systematically report lower inflation expectations. Moreover, we implement an experiment by providing firms new exogenous information about recent inflation dynamics. This experiment allows us to assess how firms respond to new information in terms of belief revisions and firm-level decisions. 


\title{
Keywords
}

liquid assets, illiquid assets, expectations, survey, inattention

\author{
JEL Classification
}

E2, E3

\section{Address for correspondence:}

(E) cama.admin@anu.edu.au

ISSN 2206-0332

The Centre for Applied Macroeconomic Analysis in the Crawford School of Public Policy has been established to build strong links between professional macroeconomists. It provides a forum for quality macroeconomic research and discussion of policy issues between academia, government and the private sector.

The Crawford School of Public Policy is the Australian National University's public policy school, serving and influencing Australia, Asia and the Pacific through advanced policy research, graduate and executive education, and policy impact. 


\title{
FIRMS' ASSET HOLDINGS AND INFLATION EXPECTATIONS
}

\author{
Saten Kumar \\ School of Economics, Auckland University of Technology \\ Centre for Applied Macroeconomic Analysis (CAMA), Australian National University
}

\begin{abstract}
This paper investigates the relationship between firms' inflation expectations and their holdings of liquid assets. We implement a new quantitative survey of firms' expectations about inflation in New Zealand. We find that firms that hold more shares of liquid assets systematically report lower inflation expectations. Moreover, we implement an experiment by providing firms new exogenous information about recent inflation dynamics. This experiment allows us to assess how firms respond to new information in terms of belief revisions and firm-level decisions.
\end{abstract}

JEL: E2, E3

Keywords: liquid assets, illiquid assets, expectations, survey, inattention

We are grateful to Olivier Coibion and Yuriy Gorodnichenko for providing constructive comments on an earlier draft of this paper. We thank the Editor and two referees for providing useful comments. We also thank seminar participants at Royal Economic Society 2018 Conference, Victoria University of Wellington, University of Otago, Auckland University of Technology, Reserve Bank of New Zealand, Massey University Albany, New Zealand Association of Economists conference for comments. Finally, we thank all research assistants for their outstanding input in the data collection. 


\section{INTRODUCTION}

Understanding how firms form expectations is crucial for understanding both firm-level decisions and aggregate outcomes. Recent literature has documented various facts about firms' beliefs about inflation (Coibion, Gorodnichenko, and Kumar, 2018 (CGK) and Kumar, Afrouzi, Coibion, and Gorodnichenko, 2015 (KACG)), but there is limited work on how these beliefs interact with firm decisions and outcomes. ${ }^{1}$ This paper explores the relationship between firms' inflation expectations and their holdings of liquid assets. Curtis, Garin and Mehkari (2017) argue that the level of inflation is an important determinant of firm-level liquid asset holdings, and moreover, liquid asset holdings have increased in many countries in recent years (Adao and Silva, 2019). We expect that firms with higher shares of liquid assets should have more incentive to track and process information about inflation. When inflation is high, firms may convert liquid assets into illiquid assets or interest-paying assets. Illiquid assets are also affected by inflation, but they have a natural defense if they appreciate or receive interest.

This paper attempts to identify a clear relationship between firms' inflation expectations and their balance sheet choices, and it further shows that manipulating inflation expectations has a direct effect on firms' decisions of how much cash to hold on the balance sheet. We implement a new quantitative survey of firms' expectations about inflation in New Zealand. Moreover, we conduct an experiment, in which we provide a randomly selected subset of firms information about recent inflation dynamics. This experiment allows us to evaluate how firms respond to new information in terms of belief revisions and firm-level decisions. This type of experiment was first introduced by CGK (2018).

We surveyed 652 firms by controlling for sectors, subsectors and firm size. The survey includes firms from the four main sectors - manufacturing, professional and financial services, trade, and construction and transportation. Our survey includes the proportion of firms that did not respond in the survey implemented by CGK (2018). Our survey also includes public trading firms. In contrast, CGK (2018) survey was implemented only on private limited companies. Specifically, we quantify the firms' beliefs about inflation according to their holdings of assets. The survey involved interviewing General Managers or Directors of the firms via phone. The response rate of the survey was around 12 percent. The survey asked questions about firms' assets, expectations about recent and future inflation, as well as questions about the basic characteristics of the firm and respondent. Respondents had to use the firms' balance sheet to respond to questions related to assets.

\footnotetext{
${ }^{1}$ CGK (2018) found that firms' inflation expectations influence their employment and investment decisions.
} 
We document several facts from this survey. First, firms hold more liquid assets than illiquid assets. Cash and trade receivables comprise the largest share of their liquid assets. The illiquid assets of firms are mostly in the form of property, plant, and equipment. Other assets held by firms are bonds, stocks, inventory, and precious commodities, however, these assets hold a small share of the total assets. Second, firms make large forecast errors about recent and future inflation. Only about half the firms in the sample made forecasts consistent with the central bank target of inflation between 1 percent and 3 percent. Comparing this result across agents, we find tremendous heterogeneity in inflation forecasts. For instance, the actual CPI inflation in Q1 2016 was 0.4\% and the Reserve Bank of New Zealand (RBNZ), professional forecasters (Consensus Economics), and households predicted 12-months-ahead inflation rate as 1.3 percent, 1.7 percent, and 2.1 percent, respectively. In our survey, the mean forecast of the 12-months-ahead inflation rate is around 3.5 percent. There is also large within-group dispersion: the cross-sectional standard deviations of the 12-months-ahead inflation rate are 2.3 percent and 1.9 percent for firms and households, respectively. This corroborates the findings from CGK (2018) and KACG (2015). Moreover, forecasts of recent and long-term inflation rates are not very different from the forecasts of 12 months-ahead inflation. The forecast of the previous 12 months inflation is approximately 3.4 percent with a standard deviation of around 1.5 percent. The long-term 5-year forecast of inflation is around 3.3 percent, and the standard deviation is around 1.8 percent.

To explore the relationship between inflation expectations and liquid asset holdings, the shares of liquid assets are divided into five quintiles. We find that firms with high liquid shares systematically report lower inflation expectations than firms that do not hold as much liquid assets on the balance sheet. Firms in the lowest quintile report an average 12 monthsahead inflation forecast of 6.6 percent, with a cross-sectional standard deviation of 2.7 percent, compared with a mean forecast of 1.9 percent, and a standard deviation of 0.6 percent for firms in the highest quintile. Regression results confirm that liquid assets and inflation forecasts are negatively correlated, controlling for firm-specific and subsector fixed effects.

Lastly, our experimental exercise on firm managers informs that there is evidence of learning. Managers revise their beliefs about inflation by allocating more weight to the new information. Particularly, managers that over-estimated their prior forecast revise down their new forecast, and those that under-estimated their prior forecast do vice-versa. In this experiment, we find evidence that beliefs affect firms' decisions. Upon receiving new information, firms not only revise their inflation expectations but also adjusts their assets. We find that the case is that between two otherwise similar firms, which also had similar inflation 
expectations, the one that was treated (and hence less uncertain about its expectations) had a higher liquid share in the subsequent 12 months. The publicly available balance sheets of public trading firms confirm the findings of this experiment.

The paper is organized as follows. Section 2 describes how the survey was implemented and presents evidence on the quality of the survey. Section 3 documents empirical findings that emerged from the survey. Finally, section 4 concludes.

\section{SURVEY}

\subsection{Survey framework}

We conducted two waves of the firm survey. The main survey (wave one) was conducted between April 2016 and September 2016. The follow-up survey (wave two) was conducted approximately after a year, i.e. between April 2017 and September 2017. ${ }^{2}$ Firm details (names, contacts, size of the workforce, etc.) were selected from the Equifax New Zealand database. Firms were classified according to the Australia and New Zealand Standard Industrial Classification (ANZSIC) 2006. The firms in this survey employ six or more workers. We ignored firms that employ less than six workers because they are too small. We considered firms from four main sectors of the economy: (i) manufacturing, (ii) professional and financial services, (iii) trade, and (iv) construction and transportation. Around 5433 firms were randomly chosen from the population of firms in New Zealand. We allowed two-thirds of the population of this survey from manufacturing and professional and financial services because both industries contribute vastly to the national gross domestic product. The remaining population consists of firms from the construction, transportation, and trade industries. In the process of randomization, we controlled for firm size, sectors, and subsectors. We used the Statistics New Zealand data for 2014 to compute the proportion of firms that fall into each employment size group (6 to 19 workers, 20 to 49 workers, and $\geq 50$ workers) for each sector. This enables us to match our population with the population of firms in the economy. Table 1 presents the firm count by industry and employment size group. For instance, the manufacturing industry in 2014 had around 65.5 percent of firms in the employment size group of 6 to 19 workers, 21.8 percent in the employment size group of 20 to 49 workers and 12.6 percent in the employment size

\footnotetext{
${ }^{2}$ The time length of each wave is around six months because the balance sheet data of firms is available either after 31 March or 30 June. Each wave includes two groups of firms. The first group was surveyed between April and June and these firms had their financial year ending 31 March. The second group was surveyed between July and September. Firms that responded in the second group had their financial year ending 30 June.
} 
group of 50 or more workers. Our population in the manufacturing industry included similar proportions. The employment size proportions were computed for professional and financial services, trade, construction, and transportation industries and our population was matched accordingly.

\{Insert Table 1 about here $\}$

This survey is different from CGK (2018) in two dimensions. First, we surveyed firms that are not included in the sampling framework of CGK (2018). Second, this survey includes both public trading firms and private limited companies. The survey implemented by CGK (2018) includes only the latter.

\subsection{Survey response}

We conducted phone surveys with the managers or directors of the firms. They were provided with the information sheet and questionnaire about a week before the phone call. This gave participants some time to consider their participation. After contacting around 5433 firms, we attained a response rate of around 12 percent, i.e. 652 responses. In the actual process of the phone interview, we recorded the responses in the hard copy questionnaire. Later, a few independent individuals were hired to verify the responses in the Excel spreadsheet to the hard copy questionnaire. The survey asked respondents a range of questions about the characteristics of the firm and the respondent, firms' balance sheet information related to their assets, and managers' expectations about recent and future inflation. The questionnaire is available in the Appendix.

Furthermore, we invited all firms from the main survey to participate in the follow-up survey. We achieved a response rate of 48 percent - that is, 311 firms. The purpose of conducting the follow-up survey was to assess the consistency of responses across the two waves as well as to investigate how firms' actions are affected when they are provided with new information. The appendix includes the questionnaire details of the follow-up survey. Moreover, we provided respondents with incentives to participate in the survey. In each wave, respondents received an entertainment voucher (dinner and drinks) of $\$ 40$ and entered a pool draw to win a cash prize of $\$ 5,000$.

The non-response of firms in the survey is large. We attempted to address the nonresponses by broadly controlling for the employment size distribution in the survey. For example, the manufacturing sector in New Zealand has 65.5 percent of firms that employ 6-19 
workers, 21.8 percent employ 20-49 workers, and 12.6 percent employ 50 or more workers. In our survey, most manufacturers employ workers between 6-19 (48.2 percent, see Table 1) and this is consistent with the Statistics New Zealand data. The survey attempted to control for employment size groups whenever possible. ${ }^{3}$

\subsection{Quality of the survey}

It is important to assess the quality of the survey data. Since firms have no direct incentive to contribute to the survey nor do they have any incentive to disclose the true information, the data collected from the survey is under validity suspect when they do not disclose true information. We verify our survey data through publicly available data, via online sources.

\subsubsection{Verification of responses via Companies Office}

We assess whether the balance sheet information provided by managers in the survey is consistent with publicly available data. This can be verified by the public trading firms as their financial statements are available in the Companies Office, The New Zealand Register of Companies. This is an electronic register where company information and documents can be filed and viewed online. In Appendix, Table 1A Panel A presents the verification details associated with the Companies Office. In this survey, 104 firms publicly trade and their recent financial statements such as balance sheets are available in the Companies Office. For more than 80 percent of the public firms in our survey, we find a very strong match between the survey responses and the information available in the Companies Office. In particular, survey responses about the shares of bonds, cash, property, plant and equipment, and precious commodities match more than 90 percent with the shares of these assets indicated in the publicly available balance sheets. For remaining firms, the overall shares of liquid assets indicated in the survey deviate only between 5 percent to 10 percent from the balance sheet records in the Companies Office.

Moreover, the survey asked managers to report the age of the firm and details about shareholding and directors. This information can be verified through the Companies Office.

\footnotetext{
${ }^{3}$ Moreover, following CGK (2018), we construct weights to ensure that our results are representative of the whole economy. To do this, we grouped firms into cells defined by firm size and industry. We used the 3-digit ANZSIC industry level of aggregation. The firm size groups considered are 6 to 19 workers, 20-49 workers, and 50 or more workers. We computed the total population employment for each cell using the data from Statistics New Zealand. Next, we calculate total employment in a cell for firms that participated in the survey. The weight for a firm in a given cell is set to the total population employment divided by the total sample employment in the cell. Extreme weights are avoided by capping weights at 100 whenever necessary. We find that the use of sampling weights did not change our results. For brevity, we do not report results using weights.
} 
Information about their age is available online for 626 firms. We find that 96 percent of the responses about reported age in the survey matches the online information. Firms that are public companies provided us information about the number of shares issued and the number of directors. For almost all firms in this survey, the responses about shareholding and directors match with the online information.

\subsubsection{Verification of responses via firms' website}

Table 1A Panel B in the Appendix reports the verification details using the firms' website information. Some firms maintain an online profile about their basic details such as ownership, products, prices, and whether they export or not. The survey asked questions related to the firms' main product, second main product, prices of main and second main products, and share of sales from overseas. The survey also asked a question about the ownership of the firm, i.e. whether the firm is domestically or foreign-owned or some share of both. The information about the main product and the second main product of the firm is available online for 566 and 490 firms, respectively. For all firms, their main product and second main product are listed as their selling products. The survey data shows 126 firms export overseas. Information about the firms' export (e.g. whether they export or not) is available via websites for only 77 firms. On this front, we find 75 out of 77 responses match the online information. Regarding firm ownership (whether ownership is domestic or foreign), we find a 100 percent match between survey responses and online information. Furthermore, we find that 284 and 265 firms listed prices online of their main product and second main product, respectively. We find a very strong match between the reported prices in the survey and indicated prices on their websites. On this front, 262 (241) firms' prices reported in the survey match with the prices indicated online for their main (second main) products.

\subsubsection{Is the manager the relevant respondent?}

Another important verification we conducted was whether the managers interviewed in this survey are relevant individuals to respond to questions about inflation forecasts and firms assets. We asked managers the question about who makes decisions in the business regarding the prices, assets, new capital investment and employment - see questionnaire in the Appendix. We find that around 72 percent of the managers in this survey selected the option 'myself only' for pricing decisions. In regards to decisions related to assets, investment, and employment, we find that around 65 percent, 75 percent and 68 percent of the managers selected the option 'myself only', respectively. Furthermore, between 25 percent and 30 percent of the respondents 
indicated that decisions on the four indicators are made by them together with other staff members. The options 'other staff member(s)' and 'someone outside of this business' accounted for less than 2 percent of the managers. Moreover, the survey asked a related question to managers about how much they contribute to each decision. Table $2 \mathrm{~A}$ in the Appendix presents the results of this question. Most of the managers in this survey responded that their contributions to each decision are 'very strongly' and 'strongly'. These results imply that the respondents in this survey are relevant individuals to answer the survey questions. There is no evidence of sample bias in this data.

\section{EMPIRICAL RESULTS}

\subsection{Liquid assets and inflation expectations}

The survey collected information about firms' asset holdings - see questionnaire in the Appendix. ${ }^{4}$ We find evidence that firms hold more liquid than illiquid assets, with trade receivables and cash being the main forms of liquid assets and property, plant, and equipment the main form of illiquid asset holdings. Table 2 reports the summary statistics related to the liquid assets of the firms. ${ }^{5}$ The liquid assets held by firms are bonds, stocks, cash, inventory, trade receivables, and other liquid assets. The liquid share of total assets is around 54 percent. The survey did not collect responses from firms on the reasons for holding higher liquid assets. However, it is pragmatic that firms may hold low-risk assets that act as an immediate financial cushion if there is any event of financial instability. It may also be that firms care more about their financial position which might be helpful for investment purposes. Stocks, bonds, and other liquid assets accounted for nearly 2 percent of the total assets. The shares of liquid assets related to trade receivables and inventory are around 22 percent. Cash includes deposit account funds (checking and savings) and certificates of deposits. Stocks include shares, mutual funds, and short-term securities. The average cash holdings of firms are around 26 percent. This may be a signal that firms have a fairly strong balance sheet, however, other factors make firms' balance sheets stronger such as intelligent working capital, balanced capital structure and income-generating capital assets. The survey did not look into these aspects of the balance sheet. We compared the balance sheets of firms in this survey with the balance sheets of U.S. public corporations. The U.S. public corporations operate on a much larger scale and they hold very large amounts of cash and net worth.

\footnotetext{
${ }^{4}$ A trial survey was run to extract information about the types of assets firms hold.

${ }^{5}$ Additional summary statistics of the survey are reported in Table $3 \mathrm{~A}$ in the Appendix.
} 
\{Insert Table 2 about here $\}$

We construct two measures of liquid assets, i.e. (i) shares of cash, bonds \& stock and (ii) shares of receivables, inventory \& others. This distinction is useful because the former measure of liquid assets may be more correlated with inflation than the latter. Figure 1 illustrates the distributions of total liquid shares (stocks, bonds, cash, receivables, inventory, and others) and the two components of liquid assets (shares of cash, bonds \& stocks and shares of receivables, inventory \& others) held by firms in the current financial year $(t)$ and the previous ( $t-1)$ financial year. The asset composition of firms over the two years is fairly consistent. Furthermore, we find that the liquid assets of public trading firms are very consistent over the last ten years. ${ }^{6}$ This implies that we do not need to worry about measuring ex-ante expectations of future asset composition because the variations in asset compositions over time are fairly minimal. There exist less disparities in holdings of liquid assets across sectors. Figure 1 also illustrates the sectoral distribution of total liquid shares, respectively. For all sectors, cash holds the most share of liquid assets, that is, between 25 percent and 27 percent of total assets. It is worth noting that there seems to be a great deal of dispersion in the share of liquid assets across firms, ranging between $20 \%$ and $80 \%$. This large variation is primarily driven by cash, bonds and stocks.

\section{\{Insert Figure 1 about here\}}

Next, we document that firms are largely inattentive to aggregate inflation. To extract information on beliefs about inflation, the survey asked managers to forecast overall price changes in the economy for the next twelve months. The average and median point forecasts of firms about inflation over the next 12 months is around 3.5 percent and 3.0 percent, respectively, and the standard deviation is 2.3 percent. ${ }^{7}$ Reported values from this survey are trimmed, dropping all inflation forecasts above $15 \%$ and below $-2 \%$. The survey also used the terms 'CPI inflation' and 'annualized inflation' instead of 'prices will change overall in the economy'. The data did not show any discrepancies related to these terminologies. Table 3 Panel A presents the 12 months-ahead inflation forecast of firms. For comparison, we also

\footnotetext{
${ }^{6}$ We looked at the annual financial statements of public trading firms for the last ten years.

7 The distributions of 12 months-ahead inflation for the sectors are fairly similar to what is reported in CGK (2018).
} 
report the actual inflation at the time of the survey as well as other available forecasts - central bank (RBNZ) forecasts, Consensus Economics (professional forecasts), and households (RBNZ Survey of Households). The average of firms' forecasts is well above the inflation target ( 1 to 3 percent) as well as exceeds the forecast of the central bank (1.3 percent), professional forecasters ( 1.7 percent) and households ( 2.1 percent). The final two survey waves implemented by CGK (2018) in 2016Q2 and Q4 show firms' inflation forecasts had declined to under 3 percent, that is, 2.8 percent and 2.7 percent, respectively. The average forecast in this survey is somewhat higher than CGK (2018) because the sample of firms in our survey may be more sensitive to large changes in gasoline prices. The short-run swings in inflation expectations due to changes in gasoline prices has been already documented in the case of U.S. households (Coibion and Gorodnichenko 2015).

Figure 2 depicts a strong negative relationship between firms' shares of total liquid assets and their forecasts of 12 months-ahead inflation. It also shows a strong negative correlation between the components of liquid assets (cash, bond \& stock, and receivables, inventory \& others) and 12 months-ahead inflation forecast. Table 3 Panel B presents the average and median of point forecasts of 12 months-ahead inflation for five quintiles of liquid assets. We use shares of total liquid assets as the measure of liquid assets. The results indicate that firms that hold larger shares of liquid assets (for example, firms in quintiles three, four and highest) systematically report lower inflation expectations than firms that hold smaller shares of liquid assets (for example, quintile 2 and lowest). On this front, the average and median forecasts in upper quintiles are around 2 percent. Firms in the lowest quintile overestimate inflation substantially; the average and median forecasts of inflation are around 7 percent and 5 percent, respectively. The average and median forecasts in quintile 2 are around 2 percent. These results support the earlier finding that firms with high shares of liquid assets systematically forecast low inflation.

\{Insert Table 3 here $\}$

Figure 3 shows the distribution of forecast errors for the next 12 months for all firms and also for the five quintiles of liquid assets. Forecast errors are computed as the difference between RBNZ and firms' beliefs about 12 months-ahead inflation. Distributions show that only about half the firms in the survey forecast inflation consistent with the RBNZ target of 2 percent. Firms that hold large shares of liquid assets make small forecast errors than firms that hold small shares of liquid assets. The inflation forecast errors across sectors are quite 
dispersed. ${ }^{8}$ The average and median of firms' forecasts across sectors are between 4 percent and 5 percent, and the standard deviations are between 2 percent and 3 percent, respectively. The firms' forecasts of recent inflation and medium-term inflation are very similar to the 12 months-ahead forecasts. ${ }^{9}$

\section{\{Insert Figures 2 and 3 about here}

Next, we run a set of firm-level regressions to explore the relationship between inflation expectations and liquid assets. We estimate the following regression:

$$
L A_{i, t}^{i}=\alpha+\phi X_{i, t}^{i}+\theta F_{i, t}^{i} \pi_{t+12}+\delta_{j}+\varepsilon_{i, t}
$$

where $L A_{i, t}^{i}$ denotes the liquid assets of firm $i$ at date $t$, which we regress on characteristics of firm $\left(X_{i, t}^{i}\right) i$ at date $t$, forecasts of 12 months-ahead inflation $\left(F_{i, t}^{i} \pi_{t+12}\right)$ of firm $i$ at date $t$ and controlling for the subsector fixed effects $\left(\delta_{j}\right)$. Table 4 presents the regression results using a wide range of variables directly related to the firm (age of the firm, number of workers, the share of trade, number of competitors, labor costs, profit margin, price relative to competitors, and firms' past price changes). Column (1) includes the shares of total liquid assets as the dependent variable. The shares of cash, bonds \& stock is the dependent variable in Column (2). The dependent variable in Column (3) includes the shares of receivables, inventory \& others. We considered the sector and subsector-specific fixed effects because they capture differences in data across the four sectors (manufacturing, professional and financial services, trade, and construction and transportation) and 17 subsectors (equipment and machinery, chemicals and metals, paper, wood, printing and furniture, food and beverage, clothing and textile, accounting, auxiliary finance and insurance, finance, insurance, rental, hiring and real estate, legal, other professional services, car, supermarket and food, hotel and food services, wholesale trade, other store retailing, and construction and transportation). However, we find that the fixed effects do not change results much and we therefore run regressions using only the subsector fixed effects.

Our main regression results (Column 1) indicate that larger firms seem to hold less liquid assets. Firms that incur large labor costs, have high profit margins, and those who have

\footnotetext{
${ }^{8}$ These results are not reported in the paper but available upon request.

${ }^{9}$ These results are not reported for brevity.
} 
higher prices relative to their competitors also seem to hold less liquid assets. We find fairly consistent results in Column (2), except that the firm size variable is statistically insignificant at the conventional levels. Most of the estimates in Column (3) are statistically insignificant at the conventional levels; only the firm age variable is statistically significant at the 10 percent level. Furthermore, we find a negative correlation between liquid assets and forecasts of inflation in all three regressions. The estimates of 12 months-ahead inflation forecast variable are statistically significant at the 1 percent level. This implies that firms that hold large liquid assets tend to have lower inflation expectations.

\{Insert Table 4 about here\}

\subsection{Experiment: new information, forecast revisions, and firms' decisions}

The regression results in Table 4 cannot address causality because both the liquid asset shares and inflation expectations are endogenous. To evaluate a causal mechanism, we conduct an experiment that generates exogenous variation in inflation expectations. We follow CGK (2018) to implement the experiment. We first select respondents for the control and treatment groups. To do this, we randomly selected half of the respondents for the treatment group; the remaining half become members of the control group. The firms in the treatment group receive new information about the recent inflation rate in New Zealand. The new information provided was as follows: 'The RBNZ statistics indicate that the price changes overall in the economy during the last 12 months was $0.4 \%$.'. Note that this new information was not provided to the control group. Both groups of firms were asked the following question at the outset and conclusion of the survey: 'During the last twelve months, by how much do you think prices changed overall in the economy?'. Finally, we conduct a follow-up survey approximately after 12 months. In the follow-up survey, we asked firms to report the approximate shares of assets the firm holds as well as provide forecasts of price changes overall in the economy over the last 12 months. The follow-up survey includes 311 firms from the main survey. This leads to 158 and 153 firms for the control and treatment groups, respectively.

We find that firms immediately revise their beliefs upon receiving the new information. Figure 4 shows the distributions of initial and revised inflation expectations of firms in the treatment group as well as inflation expectations of firms in the control group. There is clear 
evidence of learning in the treatment group of firms. ${ }^{10}$ Firms that over-estimated their prior, revise down their forecasts, and those that under-estimated their prior, revise up their forecasts. The prior and posterior forecasts of firms in the control group are fairly consistent. This finding implies that economic agents revise their beliefs immediately, thus giving more weight to the new information.

\section{\{Insert Figure 4 about here\}}

Next, we investigate, for a given level, how reducing the uncertainty surrounding the inflation expectations affects holdings of liquid assets. We compute the size of the forecast error with respect to the firms' inflation expectations of the last 12 months in the main survey. The size of the forecast error is captured by $\left|\pi_{t}-F_{i, t}^{i} \pi_{t-12}\right| . \pi_{t}$ is the actual inflation at the time of the main survey. $F_{i, t}^{i} \pi_{t-12}$ is firms' forecast of inflation for the last 12 months. Table 5 reports the average size of the forecast error for the control and treatment group of firms in the main and follow-up surveys. The average asset holdings (using three measures $-i$. shares of total liquid assets, ii. shares of cash, bonds \& stock, and iii. shares of receivables, inventory \& others) for control and treatment group of firms across the two surveys are also reported. The forecasts of recent inflation in the control group of firms across the two surveys are fairly similar. The decline in the size of the error is due to changes in actual inflation rates. At the time of the main survey, the actual inflation was only 0.4 percent. The actual inflation increased to 1.7 percent at the time of the follow-up survey. More interestingly, the treatment group of firms increased their holdings of liquid assets, particularly cash, bonds \& stocks, in the subsequent 12 months. We run regressions to exploit the impact of forecast errors on liquid assets. To do this, we estimate the following regression by incorporating the size of the forecast error, $\left|\pi_{t}-F_{i, t}^{i} \pi_{t-12}\right|$ :

$$
\Delta \log L A_{i, t}^{i}=\alpha+\gamma X_{i, t}^{i}+\beta\left|\pi_{t}-F_{i, t}^{i} \pi_{t-12}\right|+\delta_{j}+\varepsilon_{i, t}
$$

where $\Delta \log L A$ is $\log$ change in liquid assets between the main survey and follow-up survey. The firm-specific characteristics are captured by $X . \delta_{j}$ controls for the subsector fixed effects. Table 6 present the regression results of equation (2). Column (1) includes the log change in

\footnotetext{
10 'Prior' refers to the forecast of recent inflation at the outset of the main survey. 'Posterior' refers to the forecast of recent inflation at the end of the main survey.
} 
shares of total liquid assets in the control group as the dependent variable. The dependent variable in Column (2) is log change in shares of total liquid assets in the treatment group. Columns (3) and (4) include the log change in shares of cash, bonds \& stock in control and treatment groups as dependent variables, respectively. In Columns (5) and (6), the dependent variables are log change in shares of receivables, inventory \& others in control and treatment groups, respectively. The estimates of firm-specific controls are not reported. We find that the forecast error is statistically significant at 1 percent level in the treatment groups for regressions in Columns (2) and (4). Our findings imply that the treatment reduced the firms' uncertainty surrounding the inflation expectations and firms, therefore, increased their holding of liquid assets in the subsequent 12 months. In the treatment group, firms that had larger forecast errors seem to have incurred larger increases in liquid assets in the subsequent 12 months than the firms that had smaller forecast errors. The firms in the control group show minimal changes in liquid assets over the two years. With regards to the components of liquids assets, the treatment led firms to increase the shares of cash, bonds \& stocks and not so much the shares of receivables, inventory $\&$ others. This experimental exercise informs us that firms act upon their beliefs and they are sensitive to new information.

\{Insert Tables 5 and 6 about here\}

Moreover, we run firm-level regressions to confirm that firms' revisions of inflation expectations lead to adjustments to their liquid assets. Following Coibion, Gorodnichenko and Ropele (2019), we estimate the following model:

$$
\Delta \log L A_{i, t}^{i}=\alpha+\gamma X_{i, t}^{i}+\psi F_{i, t}^{i} \pi_{t+12}+\delta_{j}+\varepsilon_{i, t}
$$

where $\triangle \log L A$ is $\log$ change in liquid assets between the main survey and follow-up survey. $X$ and $\delta$ includes the firm-specific and subsector-specific controls, respectively. We instrument for the inflation expectations $\left(F_{i, t}^{i} \pi_{t+12}\right)$ using the information treatment in the main survey, which is equal to zero for the control group and recent inflation for the treatment group. The results are presented in Table 7 . We find statistically significant effects of inflation expectations on firms' liquid asset decisions. Firms in the treatment group with one percentage point higher inflation expectations increase their liquid assets by around 4.2 percent in the subsequent year. The inflation expectations seem to have larger effects on shares of cash, bonds \& stock than 
the shares of receivables, inventory $\&$ others. To this end, the increases in shares of cash, bonds $\&$ stocks and shares of receivables, inventory \& others are around 4.6 percent and 2.1 percent, respectively. The firm characteristics (not reported) did not show any significant effects in these regressions.

\section{\{Insert Table 7 about here\}}

We assess the robustness of our results in this experiment. We use the balance sheet data of public trading firms from the Companies Office to assess the quality of firm-level outcomes. The follow-up survey includes 77 public trading firms of which 38 and 39 are part of the control and treatment groups, respectively. We estimate equation (2) for a subset of firms that includes only the public trading firms. The regression results are reported in Table 8 . The definitions of dependent variables are the same as in Table 6. We exclude the firm-specific controls due to the small sample size but the regressions do allow for subsector fixed effects. Consistent with the results in Table 6, we find that the treatment group of firms have incurred larger increases in liquid assets in the subsequent 12 months. The increases in shares of total liquid assets are driven mainly by increases in shares of cash, bonds \& stock. We did not find a statistically significant relationship between shares of receivables, inventory \& others and forecast errors.

\{Insert Table 8 about here\}

\section{CONCLUSION}

This paper investigates the relationship between firms' inflation expectations and their holdings of liquid assets. To do this, we implement a new survey of firms in New Zealand. The survey was conducted on firms from four main industries: manufacturing, professional and financial services, trade, and construction and transportation. We document several facts from this survey. First, firms hold more liquid assets than illiquid assets. The former is largely characterized by cash and trade receivables and the latter is mostly in the form of property, plant, and equipment. Firms that incur large labor costs, have high profit margins, and those who have higher prices relative to their competitors seem to hold less liquid assets. We find there exists a negative correlation between firms' forecasts of inflation and liquid assets. Second, we find that firms make large forecast errors about recent and future inflation. Only 
about half the firms in the sample make forecasts consistent with the central bank target of inflation between 1 percent and 3 percent. The mean forecast of 12 months-ahead inflation rate is around 3.48 percent. The value-added of this paper is that we show that firms that hold larger shares of liquid assets systematically report lower inflation expectations. The mean 12 monthsahead forecast of firms in the highest quintile is 1.93 percent. Last, we find that firms revise down their inflation expectations upon receiving a signal. This also results in adjustments to their asset portfolios, particularly, increase in liquid assets such as cash, bonds and stock. 


\section{REFERENCES}

Adao, B. and A. Silva (2019): "The Effect of Firm Cash Holdings on Monetary Policy," unpublished manuscript.

Coibion, O. and Y. Gorodnichenko (2015): "Is the Phillips Curve Alive and Well After All? Inflation Expectations and the Missing Disinflation," American Economic Journal: Macroeconomics, 7, 197-232.

Coibion, O., Y. Gorodnichenko, and S. Kumar (2018): "How Do Firms Form Their Expectations: New Survey Evidence," The American Economic Review, 108, 26712713.

Coibion, O., Y. Gorodnichenko, and T. Ropele (2019): "Inflation Expectations and Firm Decisions: New Causal Evidence," forthcoming in The Quarterly Journal of Economics.

Curtis, C., J. Garin, and M. S. Mehkari (2017): "Inflation and the Evolution of Firm-level Liquid Assets," Journal of Banking and Finance, 81, 24-35.

Kumar, S., H. Afrouzi, O. Coibion, and Y. Gorodnichenko (2015): "Inflation Targeting Does Not Anchor Inflation Expectations: Evidence from Firms in New Zealand," Brookings Papers on Economic Activity, Fall Issue, 1-48. 
Table 1: Firm Count by Industry and Employment Size Group

\begin{tabular}{|c|c|c|c|c|c|c|c|c|c|c|c|c|}
\hline & \multicolumn{3}{|c|}{ 6-19 Workers } & \multicolumn{3}{|c|}{ 20-49 Workers } & \multicolumn{3}{|c|}{ 50+ Workers } & \multicolumn{3}{|c|}{ Total $\geq 6$ Workers } \\
\hline & $\begin{array}{c}\text { Statistics } \\
\text { NZ } \\
\text { Popn. }\end{array}$ & $\begin{array}{l}\text { Firm } \\
\text { Survey } \\
\text { Popn. }\end{array}$ & $\begin{array}{l}\text { Firm } \\
\text { Survey } \\
\text { Resp. }\end{array}$ & $\begin{array}{c}\text { Statistics } \\
\text { NZ } \\
\text { Popn. }\end{array}$ & $\begin{array}{l}\text { Firm } \\
\text { Survey } \\
\text { Popn. }\end{array}$ & $\begin{array}{c}\text { Firm } \\
\text { Survey } \\
\text { Resp. }\end{array}$ & $\begin{array}{c}\text { Statistics } \\
\text { NZ } \\
\text { Popn. }\end{array}$ & $\begin{array}{l}\text { Firm } \\
\text { Survey } \\
\text { Popn. }\end{array}$ & $\begin{array}{c}\text { Firm } \\
\text { Survey } \\
\text { Resp. }\end{array}$ & $\begin{array}{c}\text { Statistics } \\
\text { NZ } \\
\text { Popn. }\end{array}$ & $\begin{array}{l}\text { Firm } \\
\text { Survey } \\
\text { Popn. }\end{array}$ & $\begin{array}{c}\text { Firm } \\
\text { Survey } \\
\text { Resp. }\end{array}$ \\
\hline Manufacturing & $\begin{array}{c}3527 \\
(65.5 \%)\end{array}$ & $\begin{array}{c}1187 \\
(65.5 \%)\end{array}$ & $\begin{array}{c}93 \\
(48.2 \%)\end{array}$ & $\begin{array}{c}1175 \\
(21.8 \%)\end{array}$ & $\begin{array}{c}395 \\
(21.8 \%)\end{array}$ & $\begin{array}{c}61 \\
(31.6 \%)\end{array}$ & $\begin{array}{c}680 \\
(12.6 \%)\end{array}$ & $\begin{array}{c}229 \\
(12.6 \%)\end{array}$ & $\begin{array}{c}39 \\
(20.2 \%)\end{array}$ & $\begin{array}{c}5382 \\
(100 \%)\end{array}$ & $\begin{array}{c}1811 \\
(100 \%)\end{array}$ & $\begin{array}{c}193 \\
(100 \%)\end{array}$ \\
\hline Construction & $\begin{array}{c}3733 \\
(78.9 \%)\end{array}$ & $\begin{array}{c}324 \\
(78.9 \%)\end{array}$ & $\begin{array}{c}20 \\
(40.8 \%)\end{array}$ & $\begin{array}{c}738 \\
(15.6 \%)\end{array}$ & $\begin{array}{c}64 \\
(15.6 \%)\end{array}$ & $\begin{array}{c}15 \\
(30.6 \%)\end{array}$ & $\begin{array}{c}260 \\
(5.5 \%)\end{array}$ & $\begin{array}{c}23 \\
(5.5 \%)\end{array}$ & $\begin{array}{c}14 \\
(28.6 \%)\end{array}$ & $\begin{array}{c}4731 \\
(100 \%)\end{array}$ & $\begin{array}{c}411 \\
(100 \%)\end{array}$ & $\begin{array}{c}49 \\
(100 \%)\end{array}$ \\
\hline Wholesale Trade & $\begin{array}{c}2336 \\
(70.9 \%)\end{array}$ & $\begin{array}{c}204 \\
(70.9 \%)\end{array}$ & $\begin{array}{c}21 \\
(61.8 \%)\end{array}$ & $\begin{array}{c}625 \\
(18.9 \%)\end{array}$ & $\begin{array}{c}55 \\
(18.9 \%)\end{array}$ & $\begin{array}{c}6 \\
(17.6 \%)\end{array}$ & $\begin{array}{c}336 \\
(10.2 \%)\end{array}$ & $\begin{array}{c}29 \\
(10.2 \%)\end{array}$ & $\begin{array}{c}7 \\
(20.6 \%)\end{array}$ & $\begin{array}{c}3297 \\
(100 \%)\end{array}$ & $\begin{array}{c}288 \\
(100 \%)\end{array}$ & $\begin{array}{c}34 \\
(100 \%)\end{array}$ \\
\hline Retail Trade & $\begin{array}{c}3830 \\
(76.5 \%)\end{array}$ & $\begin{array}{c}334 \\
(76.5 \%)\end{array}$ & $\begin{array}{c}75 \\
(62.5 \%)\end{array}$ & $\begin{array}{c}634 \\
(12.7 \%)\end{array}$ & $\begin{array}{c}55 \\
(12.7 \%)\end{array}$ & $\begin{array}{c}22 \\
(18.3 \%)\end{array}$ & $\begin{array}{c}541 \\
(10.8 \%)\end{array}$ & $\begin{array}{c}47 \\
(10.8 \%)\end{array}$ & $\begin{array}{c}23 \\
(19.2 \%)\end{array}$ & $\begin{array}{c}5005 \\
(100 \%)\end{array}$ & $\begin{array}{c}436 \\
(100 \%)\end{array}$ & $\begin{array}{c}120 \\
(100 \%)\end{array}$ \\
\hline Accommodation and Food Services & $\begin{array}{c}4780 \\
(78.3 \%)\end{array}$ & $\begin{array}{c}416 \\
(78.3 \%)\end{array}$ & $\begin{array}{c}27 \\
(65.9 \%)\end{array}$ & $\begin{array}{c}1058 \\
(17.3 \%)\end{array}$ & $\begin{array}{c}92 \\
(17.3 \%)\end{array}$ & $\begin{array}{c}6 \\
(14.6 \%)\end{array}$ & $\begin{array}{c}265 \\
(4.3 \%)\end{array}$ & $\begin{array}{c}23 \\
(4.3 \%)\end{array}$ & $\begin{array}{c}8 \\
(19.5 \%)\end{array}$ & $\begin{array}{c}6103 \\
(100 \%)\end{array}$ & $\begin{array}{c}531 \\
(100 \%)\end{array}$ & $\begin{array}{c}41 \\
(100 \%)\end{array}$ \\
\hline Transport, Postal \& Warehousing & $\begin{array}{c}1052 \\
(63.1 \%)\end{array}$ & $\begin{array}{c}91 \\
(63.1 \%)\end{array}$ & $\begin{array}{c}14 \\
(42.4 \%)\end{array}$ & $\begin{array}{c}363 \\
(21.8 \%)\end{array}$ & $\begin{array}{c}32 \\
(21.8 \%)\end{array}$ & $\begin{array}{c}6 \\
(18.2 \%)\end{array}$ & $\begin{array}{c}252 \\
(15.1 \%)\end{array}$ & $\begin{array}{c}22 \\
(15.1 \%)\end{array}$ & $\begin{array}{c}13 \\
(39.4 \%)\end{array}$ & $\begin{array}{c}1667 \\
(100 \%)\end{array}$ & $\begin{array}{c}145 \\
(100 \%)\end{array}$ & $\begin{array}{c}33 \\
(100 \%)\end{array}$ \\
\hline Financial \& Insurance Services & $\begin{array}{c}429 \\
(71.0 \%)\end{array}$ & $\begin{array}{c}102 \\
(71.0 \%)\end{array}$ & $\begin{array}{c}60 \\
(70.6 \%)\end{array}$ & $\begin{array}{c}82 \\
(13.6 \%)\end{array}$ & $\begin{array}{c}19 \\
(13.6 \%)\end{array}$ & $\begin{array}{c}15 \\
(17.6 \%)\end{array}$ & $\begin{array}{c}93 \\
(15.4 \%)\end{array}$ & $\begin{array}{c}22 \\
(15.4 \%)\end{array}$ & $\begin{array}{c}10 \\
(11.8 \%)\end{array}$ & $\begin{array}{c}604 \\
(100 \%)\end{array}$ & $\begin{array}{c}143 \\
(100 \%)\end{array}$ & $\begin{array}{c}85 \\
(100 \%)\end{array}$ \\
\hline Rental, Hiring \& Real Estate & $\begin{array}{c}890 \\
(81.7 \%)\end{array}$ & $\begin{array}{c}210 \\
(81.7 \%)\end{array}$ & $\begin{array}{c}17 \\
(70.8 \%)\end{array}$ & $\begin{array}{c}150 \\
(13.8 \%)\end{array}$ & $\begin{array}{c}35 \\
(13.8 \%)\end{array}$ & $\begin{array}{c}6 \\
(25 \%)\end{array}$ & $\begin{array}{c}49 \\
(4.5 \%)\end{array}$ & $\begin{array}{c}12 \\
(4.5 \%)\end{array}$ & $\begin{array}{c}1 \\
(4.2 \%)\end{array}$ & $\begin{array}{c}1089 \\
(100 \%)\end{array}$ & $\begin{array}{c}257 \\
(100 \%)\end{array}$ & $\begin{array}{c}24 \\
(100 \%)\end{array}$ \\
\hline Prof., Scientific \& Technical & $\begin{array}{c}3188 \\
(74.9 \%)\end{array}$ & $\begin{array}{c}755 \\
(74.9 \%)\end{array}$ & $\begin{array}{c}27 \\
(50 \%)\end{array}$ & $\begin{array}{c}739 \\
(17.4 \%)\end{array}$ & $\begin{array}{c}175 \\
(17.4 \%)\end{array}$ & $\begin{array}{c}14 \\
(25.9 \%)\end{array}$ & $\begin{array}{c}330 \\
(7.7 \%)\end{array}$ & $\begin{array}{c}78 \\
(7.7 \%)\end{array}$ & $\begin{array}{c}13 \\
(24.1 \%)\end{array}$ & $\begin{array}{c}4257 \\
(100 \%)\end{array}$ & $\begin{array}{c}1008 \\
(100 \%)\end{array}$ & $\begin{array}{c}54 \\
(100 \%)\end{array}$ \\
\hline Administrative and Support & $\begin{array}{c}1102 \\
(65.0 \%)\end{array}$ & $\begin{array}{c}268 \\
(65.0 \%)\end{array}$ & $\begin{array}{c}14 \\
(73.7 \%)\end{array}$ & $\begin{array}{c}323 \\
(19.0 \%)\end{array}$ & $\begin{array}{c}79 \\
(19.0 \%)\end{array}$ & $\begin{array}{c}2 \\
(10.5 \%)\end{array}$ & $\begin{array}{c}271 \\
(16.0 \%)\end{array}$ & $\begin{array}{c}66 \\
(16.0 \%)\end{array}$ & $\begin{array}{c}3 \\
(15.8 \%)\end{array}$ & $\begin{array}{c}1696 \\
(100 \%)\end{array}$ & $\begin{array}{c}413 \\
(100 \%)\end{array}$ & $\begin{array}{c}19 \\
(100 \%)\end{array}$ \\
\hline
\end{tabular}

Notes: Popn. denotes population. Resp. denotes responses. The percentage share of firms out of total $\geq 6$ workers is reported in parentheses. The statistics NZ records are given for 2014 . We group firms into four industries: (i) manufacturing, (ii) professional and financial services (financial and insurance services; rental, hiring and real estate; professional, scientific and technical services; administrative and support services), (iii) trade (wholesale trade; retail trade; accommodation and food services), and (iv) construction and transportation (construction; transport; postal and warehousing). The population in our survey includes 5433 firms. Manufacturing and professional and financial services sectors includes 3622 firms, respectively, 1181 firms in each sector. Other sectors include 1811 firms. Professional and financial services industry includes $7.9 \%((604 / 7646) * 100)$ of financial and insurance services, $14.2 \%((1089 / 7646) * 100)$ of rental, hiring and real estate services, $55.7 \%((4257 / 7646) * 100)$ of professional, scientific and technical services, and $22.8 \%((1696 / 7646) * 100$ of administrative and support services. Other sectors includes $22.7 \%$ $((4731 / 20803) * 100)$ of construction, $15.9 \%((3297 / 20803) * 100)$ wholesale trade, $24.1 \%$ ((5005/20803)*100) of retail trade, 29.3\% ((6103/20803)*100) of accommodation and food services, and $8.0 \%((1667 / 20803) * 100)$ of transport, postal and warehousing. 
Table 2: Survey Summary Statistics

\begin{tabular}{|c|c|c|c|c|c|c|c|c|c|c|}
\hline \multirow{2}{*}{ Variables } & \multicolumn{2}{|c|}{ All Firms } & \multicolumn{2}{|c|}{ Manufacturing } & \multicolumn{2}{|c|}{$\begin{array}{c}\text { Professional and Financial } \\
\text { Services }\end{array}$} & \multicolumn{2}{|c|}{ Trade } & \multicolumn{2}{|c|}{$\begin{array}{l}\text { Construction and } \\
\text { Transportation }\end{array}$} \\
\hline & Mean & Std. Dev. & Mean & Std. Dev. & Mean & Std. Dev. & Mean & Std. Dev. & Mean & Std. Dev. \\
\hline \multicolumn{11}{|l|}{ Liquid Assets } \\
\hline Stocks & 2.331 & 4.669 & 0.187 & 0.782 & 7.813 & 5.850 & 0.200 & 0.977 & 0.280 & 1.158 \\
\hline Bonds & 2.011 & 4.340 & 0.109 & 0.553 & 6.813 & 5.824 & 0.108 & 0.560 & 0.354 & 1.469 \\
\hline Cash & 26.252 & 6.406 & 25.637 & 6.086 & 25.132 & 6.846 & 27.513 & 5.538 & 27.183 & 7.447 \\
\hline Trade Receivables & 16.922 & 19.341 & 17.104 & 4.987 & 15.709 & 3.713 & 17.641 & 3.968 & 17.476 & 5.109 \\
\hline Inventory & 5.344 & 6.731 & 7.938 & 6.692 & 0 & 0 & 7.297 & 7.302 & 6.451 & 6.296 \\
\hline Other Liquid Assets & 2.449 & 1.972 & 2.109 & 1.748 & 4.396 & 1.429 & 1.446 & 1.479 & 1.317 & 1.304 \\
\hline Total Liquid Assets & 55.308 & 13.019 & 53.083 & 13.221 & 59.863 & 13.806 & 54.205 & 11.260 & 53.061 & 12.324 \\
\hline Number of Observations & \multicolumn{2}{|c|}{652} & \multicolumn{2}{|c|}{193} & \multicolumn{2}{|c|}{182} & \multicolumn{2}{|c|}{195} & \multicolumn{2}{|c|}{82} \\
\hline
\end{tabular}

Notes: Each component of liquid asset is measured as the percent of total assets. 
Table 3: Forecasts of 12 Months-Ahead Inflation and Liquid Assets

\begin{tabular}{|c|c|c|c|c|c|c|}
\hline \multicolumn{7}{|c|}{ PANEL A: Agents' Forecasts of 12 Months-Ahead Inflation } \\
\hline & $\begin{array}{c}\text { (1) } \\
\text { Actual Inflation }\end{array}$ & $\begin{array}{c}\text { (2) } \\
\text { RBNZ }\end{array}$ & $\begin{array}{c}\text { (3) } \\
\text { Consensus Economics }\end{array}$ & $\begin{array}{c}\text { (4) } \\
\text { Households }\end{array}$ & $\begin{array}{c}\text { (5) } \\
\text { Firms } \\
\text { (Mean) }\end{array}$ & $\begin{array}{c}\text { (6) } \\
\text { Firms } \\
\text { (Median) }\end{array}$ \\
\hline $\begin{array}{l}12 \text { Months-Ahead } \\
\text { Inflation Forecasts }\end{array}$ & $0.40 \%$ & $1.30 \%$ & $\begin{array}{l}1.70 \% \\
(0.3 \%) \\
\end{array}$ & $\begin{array}{l}2.10 \% \\
(1.9 \%)\end{array}$ & $\begin{array}{c}3.48 \% \\
(2.30 \%) \\
\end{array}$ & $3.00 \%$ \\
\hline \multicolumn{7}{|c|}{ PANEL B: Share of Liquid Assets and Forecasts of 12 Months-Ahead Inflation } \\
\hline & & \multicolumn{5}{|c|}{ Liquid Assets Quintile } \\
\hline & & Lowest & 2nd & 3rd & 4th & Highest \\
\hline Mean forecast & & $\begin{array}{c}6.55 \% \\
(2.70 \%)\end{array}$ & $\begin{array}{c}3.73 \% \\
(0.71 \%)\end{array}$ & $\begin{array}{c}2.27 \% \\
(1.36 \%)\end{array}$ & $\begin{array}{c}2.47 \% \\
(1.64 \%)\end{array}$ & $\begin{array}{l}1.93 \% \\
(0.60 \%)\end{array}$ \\
\hline Median forecast & & $5.00 \%$ & $4.00 \%$ & $2.00 \%$ & $2.00 \%$ & $2.00 \%$ \\
\hline Observations & & 133 & 165 & 103 & 123 & 128 \\
\hline
\end{tabular}

Notes: Standard deviations in parentheses. The table presents actual inflation at the time of the survey (column 1), inflation forecasts of the RBNZ (column 2), mean forecasts from surveys and

the cross-sectional standard deviations of these forecasts (columns 3-5). The median (50 $0^{\text {th }}$ percentile) forecast of firms is column (6). Professional forecasts are from Consensus Economics.

Household forecasts are from the Survey of Households produced by the RBNZ. Central Bank forecasts are from Monetary Policy Reports of the RBNZ. Columns (5) and (6) utilizes data from

this survey. Share of total liquid assets is used in Panel B. The median forecast in Panel B is based on the $50^{\text {th }}$ percentile. 
Table 4. Inflation Expectations and Demand for Liquid Assets

Estimated model: $L A_{i, t}^{i}=\alpha+\phi X_{i, t}^{i}+\theta F_{i, t}^{i} \pi_{t+12}+\delta_{j}+\varepsilon_{i, t}$

\begin{tabular}{lccc}
\hline & $(\mathbf{1})$ & $\mathbf{( 2 )}$ & $\mathbf{( 3 )}$ \\
\hline Firm Age & -0.973 & -0.027 & $-0.946^{*}$ \\
& $(0.749)$ & $(0.588)$ & $(0.559)$ \\
Log of Employment & $-1.123^{*}$ & -0.420 & -0.702 \\
& $(0.616)$ & $(0.463)$ & $(0.481)$ \\
Share of Trade & 0.022 & 0.010 & 0.013 \\
& $(0.022)$ & $(0.014)$ & $(0.017)$ \\
Number of Competitors & 0.162 & 0.113 & 0.049 \\
& $(0.114)$ & $(0.079)$ & $(0.081)$ \\
Labor Share of Costs & $-0.114^{* *}$ & $-0.106^{* * *}$ & -0.008 \\
& $(0.052)$ & $(0.036)$ & $(0.038)$ \\
Average Profit Margin & $-0.172^{* * *}$ & $-0.144^{* * *}$ & -0.028 \\
& $(0.060)$ & $(0.043)$ & $(0.046)$ \\
Price Relative to Competitors & $-0.773^{* *}$ & $-0.663 * *$ & -0.111 \\
& $(0.374)$ & $(0.265)$ & $(0.313)$ \\
Firms' Past Price Changes & -0.265 & -0.183 & -0.082 \\
& $(0.229)$ & $(0.163)$ & $(0.178)$ \\
Forecast 12 Months-Ahead Inflation & $-1.410^{* * *}$ & $-0.437^{* * *}$ & $-0.974 * * *$ \\
\end{tabular}

Notes: Robust standard errors in parentheses. $* * * \mathrm{p}<0.01,{ }^{*} \mathrm{p}<0.05, * \mathrm{p}<0.1 . L A_{i, t}^{i}$ denotes the liquid assets of firm $i$ at date t. $X_{i, t}^{i}$ is the characteristics of firm $i$ at date $t . F_{i, t}^{i} \pi_{t+12}$ denotes forecasts of 12 months-ahead inflation of firm $i$ at date $t . \delta_{j}$ controls for subsector fixed effects. In Column (1) the dependent variable is the share of total liquid assets. The dependent variable in column (2) is shares of cash, bonds \& stock. Column (3) includes the shares of receivables, inventory \& others as the dependent variable. 
Table 5: Forecast Errors, New Information and Asset Holdings

\begin{tabular}{lccc}
\hline & $\begin{array}{c}\text { (1) } \\
\text { Control Group } \\
\text { Main Survey }\end{array}$ & $\begin{array}{c}\text { (2) } \\
\text { Control Group } \\
\text { Follow-up Survey }\end{array}$ & $\begin{array}{c}\text { (4) } \\
\text { Treatment Group } \\
\text { Main Survey }\end{array}$ \\
\hline$\left|\pi_{t}-F_{i, t}^{i} \pi_{t-12}\right|$ & 3.530 & 2.080 & 3.110 \\
Shares of Liquid Assets & 54.044 & 54.500 & 53.621 \\
Shares of Cash, Bond \& Stock & 30.051 & 30.458 & 29.614 \\
Shares of Receivables, Inventory and Other & 23.994 & 24.042 & 6.550 \\
Number of Observations & 158 & 158 & 24.007 \\
\hline
\end{tabular}

Number of Observations

Notes: The size of the forecast error is captured by $\left|\pi_{t}-F_{i, t}^{i} \pi_{t-12}\right| . \pi_{t}$ is the actual inflation at the time of the main survey. $F_{i, t}^{i} \pi_{t-12}$ is firm $i$ 's inflation forecast for the last 12 months during the time of the main survey. 
Table 6: New Information and Asset Decisions, All Firms

Estimated Model: $\Delta \log L A_{i, t}^{i}=\alpha+\gamma X_{i, t}^{i}+\beta\left|\pi_{t}-F_{i, t}^{i} \pi_{t-12}\right|+\delta_{j}+\varepsilon_{i, t}$

\begin{tabular}{lcccccc}
\hline & $(\mathbf{1})$ & $\mathbf{( 2 )}$ & $\mathbf{( 3 )}$ & $\mathbf{( 4 )}$ & $\mathbf{( 5 )}$ & $\mathbf{( 6 )}$ \\
\hline$\left|\pi_{t}-F_{i, t}^{i} \pi_{t-12}\right|$ & 0.005 & $0.145^{* * *}$ & 0.056 & $0.148^{* * *}$ & -0.036 & 0.041 \\
& $(0.038)$ & $(0.025)$ & $(0.039)$ & $(0.025)$ & $(0.053)$ & $(0.026)$ \\
\hline Constant & 0.150 & $2.106^{* * *}$ & -0.522 & $1.960^{* * *}$ & $-0.806^{*}$ & -0.162 \\
& $(0.268)$ & $(0.187)$ & $(0.427)$ & $(0.232)$ & $(0.463)$ & $(0.357)$ \\
Observations & 84 & 136 & 86 & 145 & 67 & 119 \\
Subsector Fixed Effects & Yes & Yes & Yes & Yes & Yes & Yes \\
R-squared & 0.418 & 0.355 & 0.354 & 0.441 & 0.712 & 0.249 \\
\hline
\end{tabular}

Notes: Robust standard errors in parentheses. ${ }^{* * *} \mathrm{p}<0.01,{ }^{* *} \mathrm{p}<0.05,{ }^{*} \mathrm{p}<0.1 . \Delta \log L A_{i, t}^{i}$ is $\log$ change in liquid assets of firm $i$ between the main survey and follow-up survey. The size of the forecast error is captured by $\left|\pi_{t}-F_{i, t}^{i} \pi_{t-12}\right| . \pi_{t}$ is the actual inflation at the time of the main survey. $F_{i, t}^{i} \pi_{t-12}$ is firm $i$ 's forecast of inflation for the last 12 months in the main survey. $X_{i, t}^{i}$ is the characteristics of firm $i$ reported in the main survey. $\delta_{j}$ controls for subsector fixed effects. Column (1) includes the log change in shares of total liquid assets in the control group as the dependent variable. The dependent variable in Column (2) is log change in shares of total liquid assets in the treatment group. Column (3) includes the log change in shares of cash, bonds \& stock in the control group as the dependent variable. Column (4) includes the log change in shares of cash, bonds \& stock in the treatment group as the dependent variable. In Columns (5) and (6), the dependent variables are log change in shares of receivables, inventory $\&$ others in control and treatment groups, respectively. 
Table 7: Effect of Inflation Expectations on Liquid Assets

Estimated Model: $\Delta \log L A_{i, t}^{i}=\alpha+\gamma X_{i, t}^{i}+\psi F_{i, t}^{i} \pi_{t+12}+\delta_{j}+\varepsilon_{i, t}$

\begin{tabular}{lccc}
\hline & $(\mathbf{1})$ & $\mathbf{( 2 )}$ & $\mathbf{( 3 )}$ \\
\hline$F_{i, t}^{i} \pi_{t+12}$ & $4.197^{* * *}$ & $4.591^{* * *}$ & $2.081^{* * *}$ \\
& $(0.309)$ & $(0.314)$ & $(0.359)$ \\
\hline Constant & -0.108 & $-1.228^{*}$ & 0.100 \\
& $(0.687)$ & $(0.644)$ & $(0.724)$ \\
Observations & 220 & 231 & 186 \\
Subsector Fixed Effects & Yes & Yes & Yes \\
R-squared & 0.592 & 0.601 & 0.469 \\
\hline
\end{tabular}

Notes: Robust standard errors in parentheses. $* * * \mathrm{p}<0.01, * * \mathrm{p}<0.05,{ }^{*} \mathrm{p}<0.1 . \Delta \log L A_{i, t}^{i}$ is $\log$ change in liquid assets of firm $i$ between the main survey and follow-up survey. $F_{i, t}^{i} \pi_{t+12}$ is firm $i$ 's forecast of 12 months-ahead inflation in the main survey. $X_{i, t}^{i}$ is the characteristics of the firm reported in the main survey. $\delta_{j}$ controls for subsector fixed effects. Column (1) includes log change in shares of total liquid assets as the dependent variable. Column (2) includes log change in shares of cash, bonds $\&$ stock as the dependent variable. The dependent variable in Column (3) is log change in shares of receivables, inventory \& others. 
Table 8: New Information and Asset Decisions, Public Trading Firms

Estimated Model: $\Delta \log L A_{i, t}^{i}=\alpha+\gamma X_{i, t}^{i}+\beta\left|\pi_{t}-F_{i, t}^{i} \pi_{t-12}\right|+\delta_{j}+\varepsilon_{i, t}$

\begin{tabular}{lcccccc}
\hline & $\mathbf{( 1 )}$ & $\mathbf{( 2 )}$ & $\mathbf{( 3 )}$ & $\mathbf{( 4 )}$ & $\mathbf{( 5 )}$ & $\mathbf{( 6 )}$ \\
\hline$\left|\pi_{t}-F_{i, t}^{i} \pi_{t-12}\right|$ & 0.060 & $0.130^{* * *}$ & 0.054 & $0.158^{* * *}$ & 0.011 & 0.006 \\
& $(0.050)$ & $(0.045)$ & $(0.044)$ & $(0.057)$ & $(0.059)$ & $(0.055)$ \\
\hline Constant & -0.117 & $2.322 * * *$ & -0.513 & $2.133 * * *$ & $-1.044 * *$ & -0.396 \\
& $(0.345)$ & $(0.231)$ & $(0.477)$ & $(0.295)$ & $(0.495)$ & $(0.584)$ \\
Observations & 35 & 38 & 34 & 39 & 34 & 35 \\
Subsector fixed effects & Yes & Yes & Yes & Yes & Yes & Yes \\
R-squared & 0.345 & 0.497 & 0.392 & 0.522 & 0.315 & 0.273 \\
\hline
\end{tabular}

Notes: See notes of Table 6. 

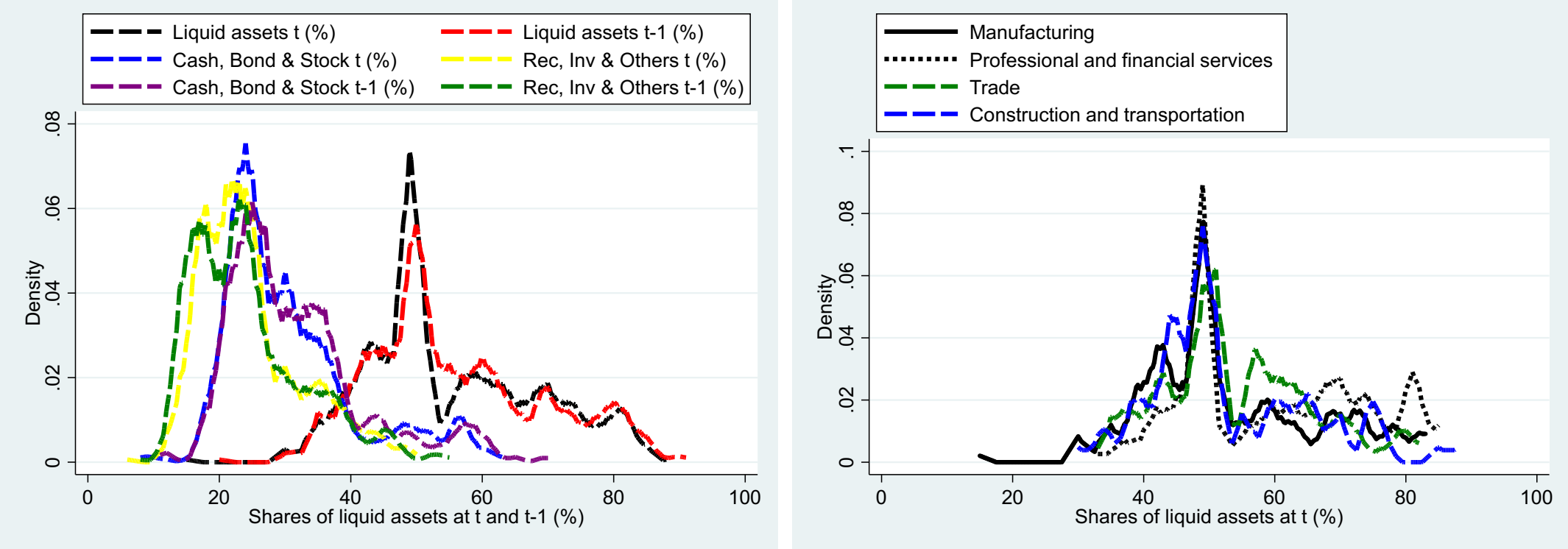

Figure 1: Plots of Liquid Asset Distributions 

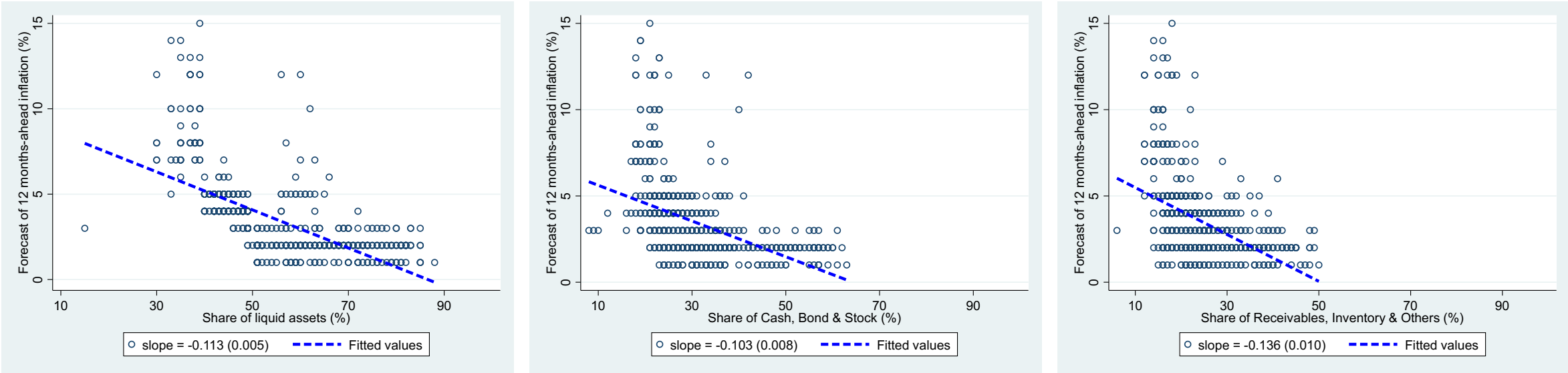

Figure 2: Share of Liquid Assets and 12 Months-Ahead Inflation Forecast 


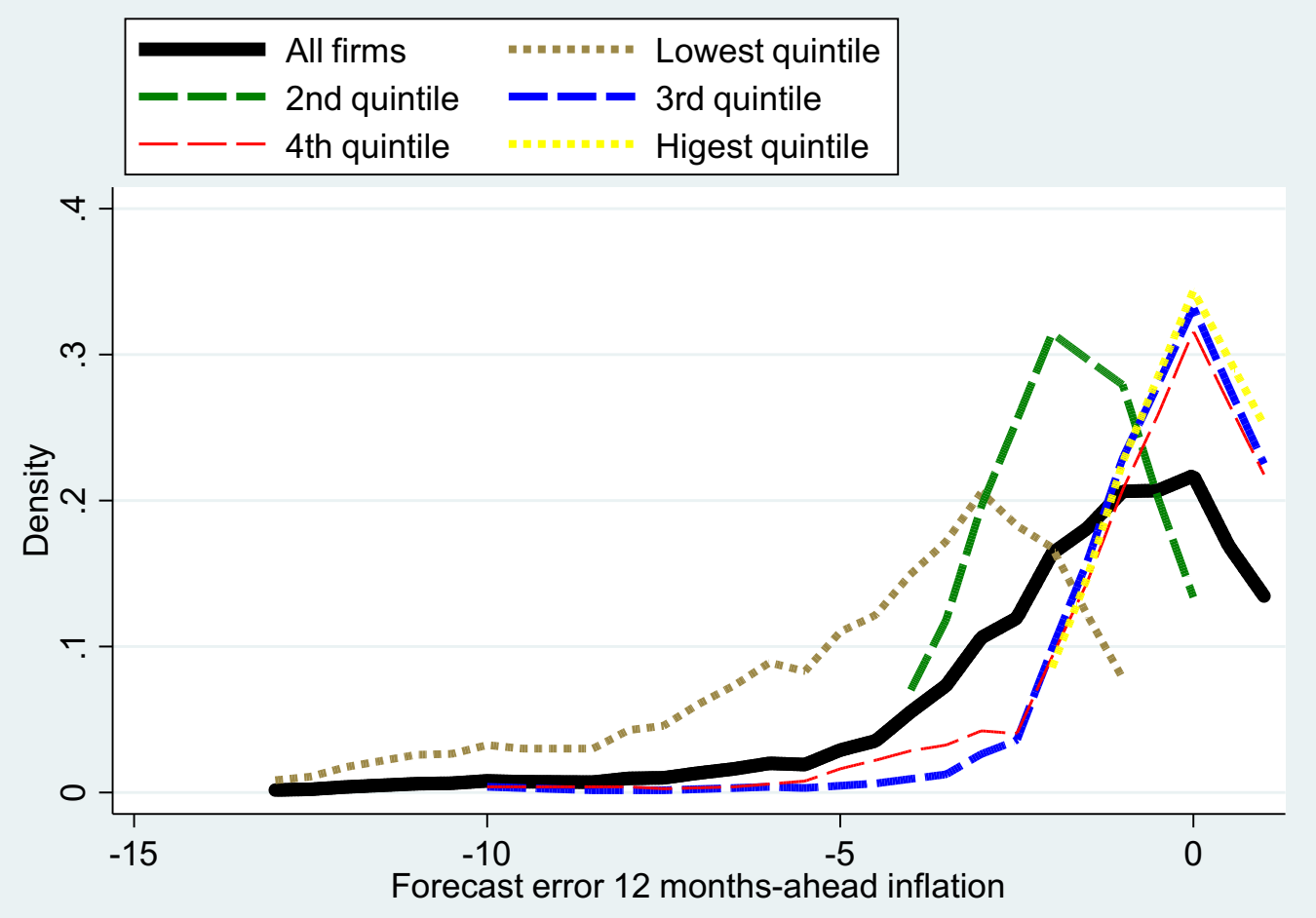

Figure 3: Forecasts Errors of 12 Months-Ahead Inflation

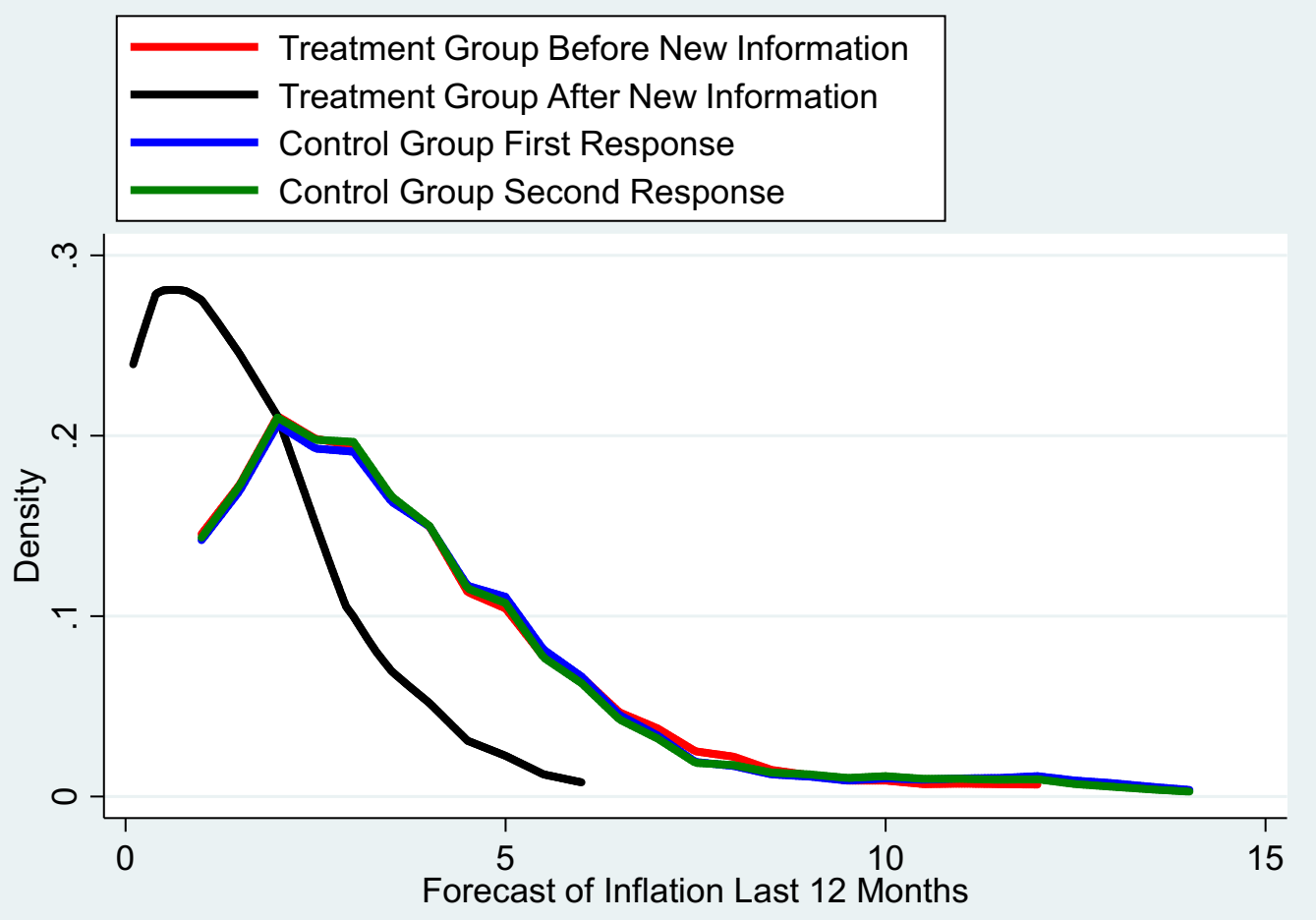

Figure 4: New Information and Revisions of Inflation Forecasts, Distributions 


\section{APPENDIX}

Table 1A: Verification of Responses

PANEL A. Survey Responses versus Records in Companies Office

\begin{tabular}{|c|c|c|c|c|c|}
\hline \multirow{2}{*}{ 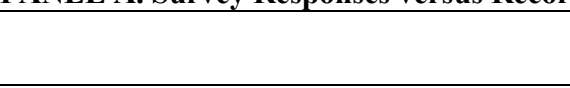 } & \multicolumn{2}{|c|}{ Responses Match with Companies Office } & \multicolumn{2}{|c|}{ Responses Do Not Match with Companies Office } & \multirow{2}{*}{$\begin{array}{c}\text { Total Number of Firms } \\
\text { Verified via Companies Office }\end{array}$} \\
\hline & Number of Firms & Percentage of Firms & Number of Firms & Percentage of Firms & \\
\hline Stocks & 92 & $88 \%$ & 12 & $12 \%$ & 104 \\
\hline Bonds & 97 & $93 \%$ & 7 & $7 \%$ & 104 \\
\hline Trade Receivables & 85 & $82 \%$ & 19 & $18 \%$ & 104 \\
\hline Cash & 100 & $96 \%$ & 4 & $4 \%$ & 104 \\
\hline Inventory & 89 & $86 \%$ & 15 & $14 \%$ & 104 \\
\hline Other Liquid Assets & 84 & $81 \%$ & 20 & $19 \%$ & 104 \\
\hline Property, Plant and Equipment & 100 & $96 \%$ & 4 & $4 \%$ & 104 \\
\hline Precious Commodities & 100 & $96 \%$ & 4 & $4 \%$ & 104 \\
\hline Other Illiquid Assets & 88 & $85 \%$ & 16 & $15 \%$ & 104 \\
\hline \multicolumn{6}{|l|}{ Age Information } \\
\hline Year of Registration & 626 & $96 \%$ & 26 & $4 \%$ & 652 \\
\hline \multicolumn{6}{|l|}{ Shareholding Information } \\
\hline Number of Shares Issued & 652 & $100 \%$ & 0 & $0 \%$ & 652 \\
\hline Number of Directors & 652 & $100 \%$ & 0 & $0 \%$ & 652 \\
\hline
\end{tabular}

PANEL B. Survey Responses versus Records on Firms' Website

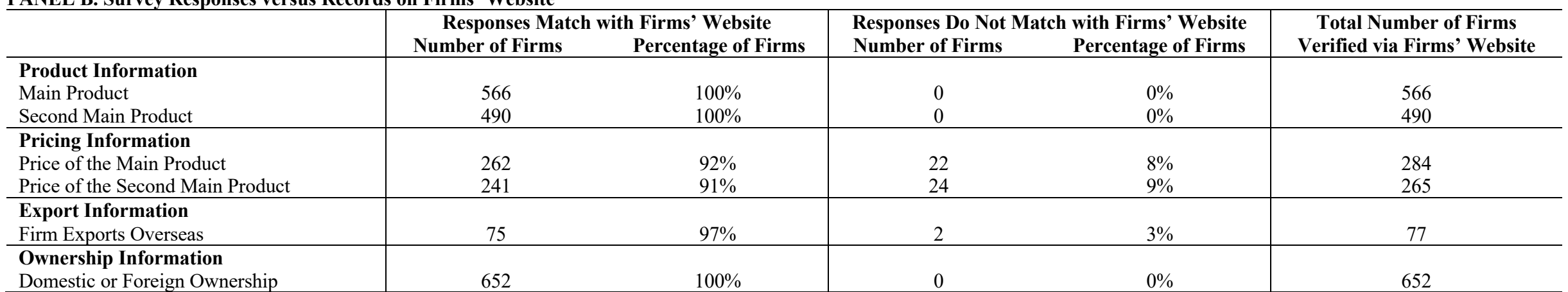


Table 2A: Managers' Input into Decision Making

\begin{tabular}{|c|c|c|c|c|c|c|c|c|}
\hline & \multicolumn{2}{|c|}{ Pricing Decisions } & \multicolumn{2}{|c|}{ Asset Decisions } & \multicolumn{2}{|c|}{ Investment Decisions } & \multicolumn{2}{|c|}{ Employment Decisions } \\
\hline & $\begin{array}{l}\text { Number of } \\
\text { Managers }\end{array}$ & $\begin{array}{c}\text { Percentage of } \\
\text { Managers }\end{array}$ & $\begin{array}{l}\text { Number of } \\
\text { Managers }\end{array}$ & $\begin{array}{c}\text { Percentage of } \\
\text { Managers }\end{array}$ & $\begin{array}{l}\text { Number of } \\
\text { Managers }\end{array}$ & $\begin{array}{c}\text { Percentage of } \\
\text { Managers }\end{array}$ & $\begin{array}{l}\text { Number of } \\
\text { Managers }\end{array}$ & $\begin{array}{c}\text { Percentage of } \\
\text { Managers }\end{array}$ \\
\hline Very Strongly & 509 & $78.1 \%$ & 568 & $87.1 \%$ & 514 & $78.8 \%$ & 520 & $79.8 \%$ \\
\hline Strongly & 112 & $17.2 \%$ & 61 & $9.4 \%$ & 105 & $16.1 \%$ & 113 & $17.3 \%$ \\
\hline Moderately & 25 & $3.8 \%$ & 20 & $3.1 \%$ & 21 & $3.2 \%$ & 14 & $2.1 \%$ \\
\hline Weakly & 4 & $0.6 \%$ & 1 & $0.1 \%$ & 8 & $1.2 \%$ & 3 & $0.5 \%$ \\
\hline Very Weakly & 2 & $0.3 \%$ & 2 & $0.3 \%$ & 4 & $0.6 \%$ & 2 & $0.3 \%$ \\
\hline Total Number of Managers & 652 & $100 \%$ & 652 & $100 \%$ & 652 & $100 \%$ & 652 & $100 \%$ \\
\hline
\end{tabular}

Notes: The table shows the number and percentage of managers that ticked each option. For example, 509 managers ticked 'very strongly' for pricing decisions, implying that 78.1 percent of respondents in this survey have a very strong involvement in price-setting decisions of the firm. 
Table 3A: Additional Summary Statistics of the Survey

\begin{tabular}{|c|c|c|c|c|c|c|c|c|c|c|}
\hline \multirow[t]{2}{*}{ Variables } & \multicolumn{2}{|c|}{ All Firms } & \multicolumn{2}{|c|}{ Manufacturing } & \multicolumn{2}{|c|}{$\begin{array}{c}\text { Professional and Financial } \\
\text { Services }\end{array}$} & \multicolumn{2}{|c|}{ Trade } & \multicolumn{2}{|c|}{$\begin{array}{l}\text { Construction and } \\
\text { Transportation }\end{array}$} \\
\hline & Mean & Std. Dev. & Mean & Std. Dev. & Mean & Std. Dev. & Mean & Std. Dev. & Mean & Std. Dev. \\
\hline \multicolumn{11}{|l|}{ Firm Characteristics } \\
\hline Firm Age & 40.747 & 32.562 & 47.492 & 35.999 & 37.258 & 29.969 & 40.051 & 32.950 & 42.220 & 26.665 \\
\hline Number of Workers & 27.560 & 24.732 & 29.233 & 26.112 & 24.049 & 22.537 & 26.585 & 25.685 & 33.732 & 22.574 \\
\hline Share of Trade & 6.363 & 16.798 & 11.979 & 22.543 & 2.209 & 8.847 & 4.595 & 14.216 & 6.573 & 16.813 \\
\hline Number of Competitors & 8.310 & 6.061 & 7.979 & 6.076 & 8.824 & 6.211 & 8.595 & 5.923 & 7.268 & 5.948 \\
\hline Labor Share of Costs & 28.771 & 12.130 & 30.731 & 120.253 & 28.736 & 12.187 & 27.308 & 12.228 & 27.720 & 11.008 \\
\hline Average Profit Margin & 22.451 & 12.204 & 23.000 & 11.336 & 21.258 & 11.260 & 21.108 & 11.311 & 29.378 & 15.541 \\
\hline Price Relative to Competitors & 2.698 & 1.503 & 2.273 & 1.547 & 2.604 & 1.493 & 2.579 & 1.474 & 2.963 & 1.469 \\
\hline Firms' Past Price Changes & 4.031 & 2.357 & 4.181 & 2.375 & 3.907 & 2.229 & 3.800 & 2.432 & 4.500 & 2.358 \\
\hline \multicolumn{11}{|l|}{ Manager Characteristics } \\
\hline Managers' Age & 36.899 & 12.844 & 39.254 & 12.843 & 37.357 & 12.517 & 34.277 & 12.351 & 36.573 & 13.749 \\
\hline Managers' Qualifications & 3.252 & 1.386 & 3.067 & 1.377 & 3.280 & 1.408 & 3.410 & 1.372 & 3.244 & 1.366 \\
\hline Managers' Experience in Firm & 8.123 & 6.849 & 9.415 & 7.036 & 9.078 & 8.311 & 6.385 & 5.417 & 7.098 & 4.550 \\
\hline Managers' Income & 2.960 & 0.836 & 2.974 & 0.850 & 3.000 & 0.828 & 2.969 & 0.843 & 2.817 & 0.803 \\
\hline Number of Observations & \multicolumn{2}{|c|}{652} & \multicolumn{2}{|c|}{193} & \multicolumn{2}{|c|}{182} & \multicolumn{2}{|c|}{195} & \multicolumn{2}{|c|}{82} \\
\hline
\end{tabular}

Notes: The survey asked managers about the age of the firm and the number of workers employed. The average age and employment of the firms are around 41 years and 28 workers, respectively. Only a very small proportion of firms sell their main products overseas; that is, the average sales from overseas is only around 6 percent. Firms face direct competition in their main product line. The average number of competitors faced by firms is around 8 . The firms compensate for all employees; the average labor cost is around 29 percent. For all firms, the sales price exceeds their operating costs. The average profit margin is around 22 percent. The survey also collected information about firms' pricing characteristics. The price of the firms' main product is around 3 percent higher relative to their competitors. The annualized price changes of their main products are around 4 percent. Moreover, the survey gathered information about the manager-specific characteristics. The average age of the respondent is around 37 years. Most of them hold university or college diplomas and have been working in the firm for around 8 years. The average income of managers is between NZ\$50,000 and NZ\$74,999. The summary statistics of this survey in most dimensions are fairly comparable with CGK (2018). However, an observable difference between the two surveys is the age of the firms. It appears that this survey includes older firms. 
Survey Questionnaires

(Selected questions below)

\section{Firm Characteristics}

\section{MAIN SURVEY}

How many years old is the firm?

Answer: years

How many workers are employed full-time in this firm?

Answer: workers

Out of the total revenues of the firm, what fraction is used for compensation of all employees and what fraction is used for the costs of materials and intermediate inputs (raw materials, energy inputs, etc...)?

Answer:

$$
\text { Labor Costs Costs of Materials and other Inputs }
$$

Share of total revenues: $\%$ $\%$

What percentage of the firm's revenues in the last 12 months came from sales overseas?

Answer:

$$
\% \text { of sales from overseas }
$$

How many direct competitors does this firm face in its main product line?

Answer:

firms

Considering your main product line, by what margin does your sales price exceed your operating costs (i.e., the cost material inputs plus wage costs but not overheads and depreciation)? Please report your current margin as well as historical or average margin for the firm.

Answer:

Current Margin

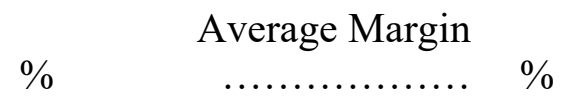

How would you compare the price of this firm's main product relative to the prices of competing products (of similar quality, characteristics, warranty)? Please provide an answer in percentage terms (e.g. "-10\%" if your product is $10 \%$ cheaper than that of most comparable competitors).

Answer:

$\%$

By how much has your firm changed the price of its main product over the last twelve months? Please provide a quantitative answer in percentage terms (e.g. "-X\%" for $\mathrm{X}$ percent decline in price, " $+\mathrm{X} \%$ " for $\mathrm{X}$ percent increase in price, etc.).

Answer:

$\%$

\section{Macroeconomic Expectations}

During the next twelve months, by how much do you think prices will change overall in the economy? Please provide an answer in percentage terms.

Answer:

$\%$ 
During the last twelve months, by how much do you think prices changed overall in the economy? Please provide an answer in percentage terms.

Answer:

$\%$

Please assign probabilities (from $0-100$ ) to the following ranges of overall price changes in the economy over the next 12 months for New Zealand: (Note that the probabilities in the column should sum to 100)

Percentage Price Changes in 12 Months Probabilities

More than 5\%:

From 4 to 5\%:

From 3 to $4 \%$ :

From 2 to 3\%:

From 1 to 2\%:

From 0 to $1 \%$ :

Less than $0 \%$ :

Total (the column should sum to 100\%):

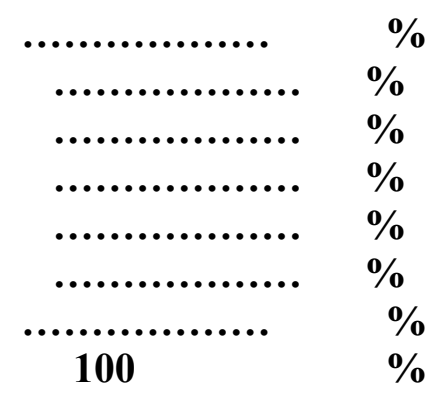

Please assign probabilities (from $0-100$ ) to the following ranges of overall price changes in the economy over the last 12 months for New Zealand: (Note that the probabilities in the column should sum to 100)

Percentage Price Changes in 12 Months Probabilities

More than 5\%:

From 4 to 5\%:

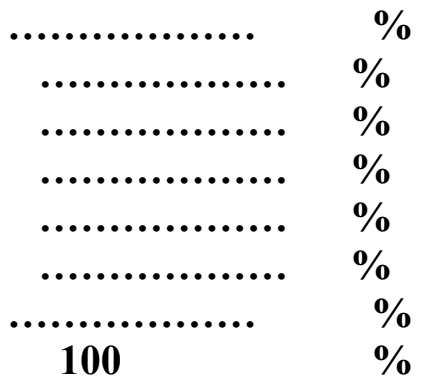

From 3 to $4 \%$ :

From 2 to 3\%:

From 1 to $2 \%$ :

From 0 to $1 \%$ :

Less than $0 \%$ :

Total (the column should sum to $100 \%$ ):

100

Over the next five years, by how much do you think prices will change overall in the economy? Please provide an answer in percentage terms.

Answer:

$\%$

\{Randomly allocate firms into three groups. For first group, ask the above questions.

For second and third groups, ask the above questions using the term 'CPI Inflation' and 'annualized inflation', respectively\}

\section{$\underline{\text { Respondent Characteristics }}$}

What is your age?

Answer:

years

What is your highest educational qualification? (Choose one of the following)

1. Less than high school 2. High school diploma 3 . University or college diploma 4.

Bachelors or honours degree 5. Graduate studies (Postgrad Dip or Masters or PhD)

How many years of work experience do you have in this firm? 
How much is your gross income per annum? (Choose one of the following)
1. Less than $\$ 30,000$
2. 30,000-49,999
3. 50,000-74,999
$75,000-99,999$
5. 100,000-149,999
6. 150,000 or more

4.

Who makes decisions in the business regarding price setting of the main product, assets, new capital investment and employment of new workers? Please tick the relevant option.

Myself only

Pricing Assets Investment Employment

Myself and other staff member(s)

Other staff member(s)

Someone outside of this business

How much do you contribute to the decisions related to price setting of the main product, assets, new capital investment, and employment of new workers? Please tick the relevant option for each decision.

Very Strongly

Pricing

Assets

Investment

Employment

Strongly

Moderately

Weakly

Very Weakly
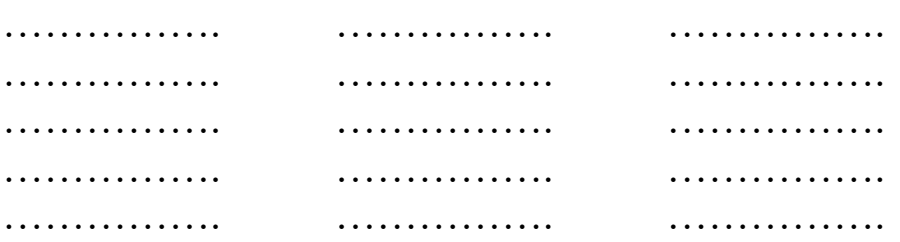

\section{Assets Details}

Use your firms' balance sheet as at $\mathrm{XX} / \mathrm{XX} / 2016$ to answer this question. What types of assets does your firm hold? (Indicate the approximate shares for each type of asset, e.g. stocks hold $10 \%$ of the total assets. The total shares should sum to $100 \%$.) Liquid Assets

Stocks (e.g. shares, mutual funds, short-term securities etc): $\%$

Bonds: $\%$

Trade and receivables: $\%$

Cash (e.g. deposit account funds, certificate of deposits etc):

Inventory: .. \%

Other liquid assets: $\%$

Illiquid Assets

Property, plant and equipment:

Precious commodities:

Other illiquid assets:

Use your firms' balance sheet as at $\mathrm{XX} / \mathrm{XX} / 2015$ to answer this question. What types of assets were held by your firm last year? (Indicate the approximate shares for each type of asset, e.g. stocks hold $10 \%$ of the total assets. The total shares should sum to $100 \%$.)

\section{Liquid Assets}

Stocks (e.g. shares, mutual funds, short-term securities etc): $\%$ Bonds: $\%$

Trade and receivables: $\quad$....... \% Cash (e.g. deposit account funds, certificate of deposits etc): Inventory: $\%$ 
Other liquid assets: $\%$

\section{Illiquid Assets}

Property, plant and equipment:

Precious commodities:

Other illiquid assets:

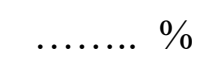

What types of assets does your firm expect to hold in the next financial year? (Indicate the approximate shares for each type of asset, e.g. stocks hold $10 \%$ of the total assets. The total shares should sum to $100 \%$ )

Liquid Assets

Stocks (e.g. shares, mutual funds, short-term securities etc):

Bonds: $\%$

Trade and receivables: $\%$

Cash (e.g. deposit account funds, certificate of deposits etc):

Inventory: $\%$

Other liquid assets: $\quad$.......\%

Illiquid Assets

Property, plant and equipment:

Precious commodities:

Other illiquid assets:

$\ldots \ldots \ldots \% \%$
......... \% $\%$

\section{Experiment}

For all private limited companies, randomly assign firms into two groups, Group A and Group B. Group A is the control group which includes 274 firms. Group B is the treatment group including 274 firms. The public companies are randomly assigned into two groups, Group C and Group D with 52 firms, respectively. Group C is the control group. Group D is the treatment group.

The treatments groups (Groups B and D) receive new information about recent inflation. Control groups receive no information.

New information for treatment groups: The RBNZ statistics indicate that the overall price changes in the economy during the last 12 months was $0.4 \%$. In light of this, we would like to ask you a follow-up question.

During the last twelve months, by how much do you think prices changed overall in the economy? Please provide an answer in percentage terms.

Answer:

$\%$

\section{FOLLOW-UP SURVEY}

During the last twelve months, by how much do you think prices changed overall in the economy? Please provide an answer in percentage terms.

Answer:

$\%$

Use your firms' balance sheet as at $\mathrm{XX} / \mathrm{XX} / 2017$ to answer this question. What types of assets does your firm hold? (Indicate the approximate shares for each type of asset, e.g. stocks hold $10 \%$ of the total assets. The total shares should sum to $100 \%$.) Liquid Assets

Stocks (e.g. shares, mutual funds, short-term securities etc): $\%$ 
Bonds: $\%$

Trade and receivables: $\%$

Cash (e.g. deposit account funds, certificate of deposits etc):

...... \%

Inventory: $\%$

Other liquid assets: $\%$

Illiquid Assets

Property, plant and equipment:

Precious commodities:

$\ldots \ldots \% \%$

Other illiquid assets: $\%$

What types of assets does your firm expect to hold in the next financial year? (Indicate the approximate shares for each type of asset, e.g. stocks hold $10 \%$ of the total assets. The total shares should sum to $100 \%$ )

Liquid Assets

Stocks (e.g. shares, mutual funds, short-term securities etc): $\%$

Bonds: $\%$

Trade and receivables: $\%$

Cash (e.g. deposit account funds, certificate of deposits etc):

Inventory: ....... \%

Other liquid assets:

Illiquid Assets

Property, plant and equipment: $\%$

Precious commodities:

........ \%

Other illiquid assets: $\%$ 